\title{
POPULAÇÃO CARCERÁRIA: UMA ANÁLISE DO RELATÓRIO FINAL DO MUTIRÃO CARCERÁRIO REALIZADO PELO CONSELHO NACIONAL DE JUSTIÇA NO BIÊNIO 2010/2011
}

\section{PRISON POPULATION: AN ANALYSIS OF THE FINAL REPORT ABOUT THE PRISON SYSTEM CAMPAIGN, DEVELOPED BY NATIONAL COUNCIL OF JUSTICE DURING 2010/2011}

\author{
Gabriel de Freitas Ribeiro* \\ Maria Geralda de Miranda* \\ Reis Friede
}

Resumo: O presente artigo tem como propósito abordar alguns pontos relevantes relacionados à população carcerária, utilizando como baseda abordagem o relatório final do Mutirão Carcerário realizado pelo Conselho Nacional de Justiça(CNJ) no biênio 2010/2011. Buscou-se inicialmente tecer comentários sobre o sistema prisional brasileiro, especialmente no que tange à superlotação e às rebeliões,para em seguida abordar o Mutirão Carcerário, instituído pela Lei n 12.106/2009com o propósito de verificar as condições de encarceramento, as ações de reinserção social dos presos e o andamento dos processos criminais,garantindo o princípio do devido processo legal. O trabalho visa uma série de reflexões críticas sobre a realidade vivida pela massa dos encarcerados, população relativamente jovem, de pouca ou nenhuma instrução, oriunda da periferia, que em sua grande maioria é composta por negros, pobres e membros de famílias de baixa renda.

Palavras-chave: População carcerária. Mutirão Carcerário.Sistema Penitenciário Brasileiro. Direitos Humanos.

Abstract: The purpose of this article is discussing some important points related to the prison population, using as its approach basis the final report about the prison system campaign, developed by National Council of Justice (CNJ), during 2010/2011. First, comments about the Brazilian prison system was made, specially, about overcrowding and rebellions. Then, the prison system campaign implemented by law $n^{\circ} 12.106 / 2009$, in order to verify the prison system conditions, the social

\footnotetext{
* Bacharel em Direito pelo Centro Universitário Augusto Motta - UNISUAM (2016) e Pós-graduado em Docência do Ensino Superior pela UNISUAM (2017). Atualmente especializando-se em Advocacia Pública pela Universidade Estadual do Rio de Janeiro (UERJ)

Mestre em Literatura Comparada com ênfase nos estudos culturais pela Universidade Federal Fluminense (UFF) e Doutora em Letras com ênfase em estudos pós-coloniais, também pela UFF. Professora do Programa de Pós-Graduação em Desenvolvimento Local, do Centro Universitário Augusto Motta, UNISUAM.

Reis Friede é Desembargador Federal, Diretor do Centro Cultural da Justiça Federal (CCJF), Mestre e Doutor em Direito. Professor e Pesquisador do Programa de Mestrado em Desenvolvimento Local do Centro Universitário Augusto Motta (UNISUAM), no Rio de Janeiro. Site:

https://reisfriede.wordpress.com/. E-mail: reisfriede@hotmail.com
} 
prisoner's recovery and the criminal process progress, ensuring the suitable legal process, was analyzed. The research makes several critical analysis about the prisoner's reality. They are, in terms, a young population, with little or no instruction, from periphery, formed, basically, by black and poor people.

Keywords: Prisoners. Prison system campaign. Brazilian prison system. Human Rights. 


\section{INTRODUÇÃO}

É sabido de todos que o sistema prisional brasileiro atravessagravíssimos problemas, tais como: superlotação, atendimento precário às necessidades básicas dos presos, desrespeito e violações aos direitos fundamentais, ociosidade, altos custos sociais e econômicos dos estabelecimentos penais, presença marcante de facções criminosas nas unidades prisionais, assassinatos, permanência de encarcerados que já cumpriram penas, prédios em estado de deterioração, ambientes fétidos e insalubres, rebeliões, torturas, fugas, espancamentos, disseminação de doenças sexualmente transmissíveis e doenças respiratórias.

Com base nas informações do Ministério da Justiça, tal sistema é hoje o terceiro maior do mundo, contando com 726.612 presos, ficando atrás apenas dos Estados Unidos com 2.145.100 pessoas privadas de liberdade e da China com 1.649.804 encarcerados. A Rússia ocupa o quarto lugar no mundo com 646.085 presos (BRASIL, [20--?]).

De acordo com o programa de coleta de dados do sistema penitenciário no Brasil (IFOPEN), entre os anos 2000 e 2014, a taxa de aprisionamento apresentou um aumento de $119 \%$. Enquanto que, no ano 2000, para cada 100 mil habitantes, havia 137 presos, em 2014 essa taxa chegou a 299,7 presos para a mesma quantidade de habitantes, ou seja, em pouco mais de uma década, a população carcerária cresceu assustadoramente. Caso o ritmo de encarceramento for mantido na mesma cadência, o Brasil terá mais de um milhão de pessoas presas em 2022 e se o compasso persistir no mesmo andamento, no ano de 2075 a cada dez habitantes, pelo menos um estará com a sua liberdade privada (BRASIL, 2014a, p. 16).

Quais seriam as soluções para estes problemas?Construções de novas unidades prisionais? Libertação dos presos de bom comportamento? Liberdade aos presos provisórios? Substituição das penas privativas de liberdade por restritivas de direitos?

Perguntas como estas são feitas todos os dias ao longo de décadas, quer seja por pessoas simples ou por renomados especialistas no assunto. Ao que parece é que o país constituído em Estado Democrático de Direito em consonância 
com sua Carta Magna mais conhecida como Constituição Cidadã que objetiva construir a cada dia uma sociedade justa e solidária sobre o firme alicerce da dignidade da pessoa humana, ainda não encontrou melhores maneiras para lidar com as problemáticas que estão ao redor do famigerado sistema penitenciário.

A Constituição Federal, bem como a legislação infraconstitucional e tratados internacionais dos quais o Brasil é signatário, estabelecem que a prisão durante o processo seja destinada somente em casos excepcionais, sendo esta garantia embasada no princípio da presunção de inocência, ou seja, o acusado deveria aguardar o julgamento na prisão somente em situação extraordinária. Esta é a regra no nosso ordenamento jurídico -liberdade durante o processo (LEMGRUBER; FERNANDES 2011, p. 23).

\section{O SISTEMA PRISIONAL BRASILEIRO E A SUPERLOTAÇÃO}

No que diz respeito à superlotação, os dados apresentados pelo Departamento Penitenciário Nacional (DEPEN) comprovam que as unidades prisionais em todo país, estão com a quantidade de internos acima das vagas disponíveis. No estado de São Paulo, por exemplo, onde concentra o maior número de presos do país, em dezembro de 2008, havia 144.522 internos em um sistema que dispunha de 99.605 vagas distribuídas entre 132 unidades. Em Roraima, na mesma época, concentrava a menor quantidade presos no cenário nacional e o problema da superlotação também assolava este ente federativo, com uma população carcerária de 1.493 pessoas para um sistema de apenas 538 vagas em um total de cinco estabelecimentos prisionais (BRASIL, 2008, p. 27, 29).

O Conselho Nacional de Justiça (CNJ) apresentou em 2014 a soma total da nossa população carcerária, que contava com 715.592 pessoas em um sistema com 357.219 vagas (BRASIL, 2014a, p. 17).

Segundo os dados do IFOPEN, o que faz elevar a quantidade de presos causando a superlotação são os presos provisórios (aqueles que ainda não foram condenados), eles já somam cerca $40 \%$ da população prisional, que, em números, 
seria, aproximadamente, 250 mil pessoas aprisionadas ainda antes de serem julgadas em primeiro grau de jurisdição (BRASIL, 2014b, p. 8).

Não há como falar em presos provisórios sem falar no Princípio da Razoabilidade consagrado na Constituição Federal. A importância deste princípio se reveste de especial relevância em face da superlotação que o sistema prisional brasileiro vem enfrentando. O inciso LXXVIII do Artigo $5^{\circ}$ da CRFB assevera que "a todos, no âmbito judicial e administrativo, são assegurados a razoável duração do processo e os meios que garantam a celeridade de sua tramitação" e a Convenção Americana sobre Direitos Humanos (Pacto de São José da Costa Rica), da qual o Brasil é signatário, testifica em seu artigo $7^{\circ}$ inciso 5 que,

Toda pessoa presa, detida ou retida deve ser conduzida, sem demora, à presença de um juiz ou outra autoridade autorizada pela lei a exercer funções judiciais e tem o direito de ser julgada dentro de um prazo razoável ou a ser posta em liberdade, sem prejuízo de que prossiga o processo. Sua liberdade pode ser condicionada a garantias que assegurem o seu comparecimento em juízo.

Nesse contexto, não se pode olvidar que, há vagas suficientes nas penitenciárias para aqueles que realmente já foram condenados através de sentença transitada em julgado, porém o fenômeno da superlotação se dá como demonstrado, em face dos presos provisórios, estes são os que extrapolam o limite da capacidade do sistema carcerário, corroborando com a grave inobservância dos princípios da Razoabilidade e do Devido Processo Legal.

Ao ser inserido o inciso LXXVIII no Art. $5^{\circ}$ na Nova Carta Política através da Emenda Constitucional $n^{\circ} 45$, de 30 de dezembro de 2004, os dados deveriam indicar o número de presos provisórios em escala cada vez mais decrescente, uma vez que tal inciso tem guarida no rol dos direitos e garantias fundamentais, mas o interessante é que, exatamente depois da inserção do dispositivo em comento, o número de presos provisórios veio crescendo cada vez mais e em escala alarmante.

Os dados do DEPEN mostram que no ano 2000 a quantidade de presos provisórios era de 80.775 , no ano de 2004 subiu para 86.766 . A partir de 2005 se tal dispositivo tivesse sido observado, os dados mostrariam diminuição desses números, mas em afronta ao consagrado preceito, em 2008 os números saltaram 
para 138.939, em 2012 avançou para 195.036 e chegando a 249.668 em 2014 (BRASIL, 2014b, p. 22). Situação verdadeiramente contraditória para um país que garante em seu ordenamento jurídico o princípio da presunção de inocência.

Com o fito de evitar a prisão do indiciado ou do acusado antes do julgamento, o que vem causando o descontrole no aumento da população carcerária e causando o problema da superlotação no sistema, a Lei $n^{0} 12.403$ de 04 de maio de 2011 trouxe alterações aos dispositivos do Código de Processo Penal no que diz respeito à prisão, às medidas cautelares e à liberdade provisória, apontando as opções que estão disponíveis ao juiz em casos de prisão em flagrante (AUDIÊNCIA, 2015). Mediante tais alterações, o Conselho Nacional de Justiça (CNJ), o Tribunal de Justiça do Estado de São Paulo (TJSP) e o Ministério da Justiça organizaram-se em parceria e lançaram no mês de fevereiro do ano de 2015 o projeto audiência de custódia, garantindo a apresentação do preso a um juiz no caso de prisão em flagrante no prazo de 24 horas. Neste aspecto, o preso deve ser imediatamente encaminhado para ser entrevistado pela autoridade judiciária em uma audiência com a presença do Ministério Público, da Defensoria Pública ou do advogado do preso.

No decorrer da audiência, o Juiz fará a análise da legalidade da prisão, sua necessidade e adequação, a possibilidade da concessão de liberdade com ou sem a imposição de outras medidas cautelares, além de avaliar se houve ou não ocorrência de torturas, maus tratos ou outros tipos de irregularidades. Durante o lançamento do projeto o então presidente do CNJ, ministro Ricardo Lewandowski atestou que,

O preso custa, em média, $\mathrm{R} \$ 3$ mil reais por mês ao Estado. Se lograrmos implantar as audiências de custódia em todo o país até 2016, isso poderá resultar em economia de $R \$ 4,3$ bilhões que poderão ser aplicados em educação, saúde, transporte público, e outros serviços (PAÍS..., 2015).

Tal projeto, que já está sendo aplicado em alguns Estados da federação e que pretende frear o avanço em número da população prisional, nada mais é que a garantia do princípio da razoabilidade, do devido processo legal e da dignidade da pessoa humana consagrados na Constituição Federal e nos demais tratados internacionais em que o Brasil é parte integrante como é o caso do Pacto de São 
José da Costa Rica, cumprindo o que estabelece em seu artigo $7^{\circ}$ inciso 5 como bem demonstrado em linhas anteriores.

\section{O SISTEMA PRISIONAL BRASILEIRO E AS REBELIÕES}

Além do problema da superlotação, merecem destaque também as rebeliões, que tem sido prática constante dentro do sistema penitenciário brasileiro, como a afamada rebelião do Carandiruno Estado de São Paulo em 1992,que teve início com um desentendimento entre dois detentos suscitando uma carnificinaque ficou internacionalmente conhecida como o massacre do Carandiru,devido à quantidade de vítimas e pelo modo em que os presos foram abordados pela Polícia Militar para conter o motim. No episódio foram mortos 111 detentos e mais de 100 ficaram feridos (SAIBA..., 2006).

Em 2001, a organização criminosa Primeiro Comando da Capital (PCC) promoveu uma rebelião tamanha que ficou conhecida como a megarrebelião. 0 motim foi sincronizado entre 29 unidades prisionais do Estado de São Paulo em um domingo à tarde, exatamente no horário de visitas com o fito de chamar a atenção das autoridades.Tal rebelião foi desencadeada como protesto pelo fato de alguns líderes do PCC terem sido transferidos da Casa de detenção do Carandiru (extinta em 2002) para unidades prisionais do interior do Estado. Na ocasião, morreram cinco detentos e quase cinco mil parentes, amigos e familiares de presos foram feitos reféns. O episódio demonstrou a força e a capacidade de organização da facção, assombrando toda população paulista (EM 2001..., 2006).

No Complexo Penitenciário de Pedrinhas (CPP) em São Luís, capital maranhense, durante o ano de 2013 ocorreram várias rebeliões que resultaram em mais de 40 mortes, obtendo repercussão internacional e levando o país a ser condenado pela Corte Interamericana de Direitos Humanos (CIDH), a adotar imediatamente, mecanismos necessários de proteção à vida e a integridade pessoal de todos os presos do CPP, inclusive a dos agentes penitenciários e visitantes, entre outras medidas, como: a redução da superpopulação. (CORTE INTERAMERICANA DE DIREITOS HUMANOS, 2013). 
No dia $1^{\circ}$ de janeiro de 2017 mais uma violenta rebelião foi desencadeada no sistema prisional brasileiro, desta vez no Complexo Penitenciário Anísio Jobim (Compaj) em Manaus, AM, que durou cerca de 17 horas de pânico. Durante o conflito armado entre duas organizações criminosas, o PCC e a Família do Norte (FDN), os pátios do Compaj ficaram totalmente lavados de sangue. Agentes penitenciários que estavam no plantão foram feitos reféns e mais de 50 detentos morreram. Após o motim, cerca de 40 cabeças e mais de uma centena de pedaços de corpos encontrados no local do massacre foram levadas ao Instituto Médico Legal de Manaus (REBELIÃO..., 2017).

Ainda dentro da mesma semana em que ocorreu o massacre no Compaj, na madrugada de sexta-feira dia 6, na Penitenciária Agrícola de Monte Cristo (PAMC) em Boa Vista, RR, 33 detentos foram mortos brutalmente como no massacre de Manaus. A maioria das vítimas foi decapitada. De acordo com informações do governo estadual, alguns detentos quebraram os cadeados e invadiram a ala em que estavam os presos de menor periculosidade e os executaram. Quatro meses antes deste pânico, a mesma penitenciária foi palco de uma rebelião entre facções que resultou em uma fogueira no pátio da unidade com sete corpos em chamas enquanto três detentos teriam sido degolados. (AO MENOS..., 2017).

No que concerne às rebeliões, Salla (2006) assevera que,

Nos últimos dez anos, têm sido comuns as rebeliões nas prisões brasileiras que deixam um sangrento rastro de mortes entre os presos. Tais mortes não derivam da ação policial de contenção desses movimentos, mas na sua maioria são provocadas por outros presos, em função de conflitos internos, das disputas entre grupos criminosos. Assim, além de denunciarem condições precárias de encarceramento que continuam a predominar no Brasil, as rebeliões têm revelado uma baixa capacidade do Estado em controlar a dinâmica prisional, em fazer valer princípios fundamentais de respeito à integridade física dos indivíduos presos, permitindo que grupos criminosos imponham uma ordem interna sobre a massa de presos (SALLA, 2006, p. 277).

Apenas as rebeliões relatadas neste tópico, resultaram em mais de 250 mortes no sistema penitenciário. O efeito dessas rebeliões acaba afetando a integridade física e a dignidade humana de toda população carcerária, trazendo dor 
e sofrimento aos amigos, parentes e familiares das vítimas,além de colocar em risco a segurança dos funcionários e da própria sociedade, afrontando preceitos consagrados na Carta Magna, na Lei de Execução Penal e nos tratados internacionais dos quais o país é subscritor.

\section{O MUTIRÃO CARCERÁRIO 2010/2011}

O Conselho Nacional de Justiça realiza desde 20080 Mutirão Carcerário, instituído pela Lei no 12.106/2009.Este projeto reúne juízes que percorrem todos os Estados da federação com a incumbência de inspecionar as unidades prisionais verificando as condições de encarceramento, acompanhando as ações de reinserção social e o andamento dos processos, garantindo o princípio do devido processo legal, o cumprimento da Lei de Execução Penal e os direitos fundamentais dos presos.

Durante os anos de 2010 e 2011, a equipe do Mutirão Carcerário percorreu as unidades da federação, com a missão acima citada. Ao todo, 310 mil processos foram analisados, o que resultou na soltura de 24,8 mil presos que já tinham direito à liberdade. Mais de 48 mil benefícios foram concedidos, como: alvarás de soltura, progressão de pena, direito a trabalho externo, entre outros. Sem dúvida, foi um dos maiores programas de direitos humanos do país (BRASIL, 2012, p. 91).Os tópicos a seguir, apresentam um resumo do relatório desta ação, organizados por regiões.

\subsection{Região Norte}

No Norte do país, a equipe do Mutirão Carcerário encontrou presos vivendo em celas sujas, escuras, mal ventiladas, insalubres e os apenados ainda contavam com um sofrimento extra, o calor amazônico. No Complexo Penitenciário Francisco D'Oliveira na Capital do Acre, a equipes e deparou com a falta de água. Em algumas unidades prisionais de Rondônia, quatro presos eram encarcerados onde só poderia estar um.No município de Augustinópolis em Tocantins,um adolescente foi apreendido na mesma cela de presos de maior idade e foi identificada a existência de apenas uma carceragem destinada a mulheres. No Amazonas, seis em cada dez 
detentos ainda aguardavam julgamento. No Amapá, uma colônia penal erguida há trinta anos, de modo improvisado, funcionava como único presídio da região, onde $10 \%$ de cerca de 1,8 mil internos haviam fugido dado o estado precário do estabelecimento. Metade dos internos, à época da inspeção, dormia no chão por falta de cama ou colchões e o mau cheiro de fezes e urina, tomava conta do ambiente. Para alguns detentos eram negados direitos básicos a exemplo do banho de sol pelo fato de estarem aprisionados em delegacias por falta de estrutura do sistema (BRASIL, 2012, p. 11-12).

\subsection{Região Nordeste}

No Nordeste, a condição subumana imposta a milhares de pessoas que cumpriam pena, se dava dentro de edifícios históricos construídos há mais de quarenta anos que clamavam por urgente manutenção. Nesses assombradores casarões os presos disputavam espaço para sobreviver, criando esquemas de revezamento para dormir, necessidade fisiológica e fundamental de todo ser humano. No Complexo Prisional Aníbal Bruno, em Pernambuco, os presos administravam as quatorze cantinas e ainda trabalhavam como ambulantes, vendendo em carrinhos ou em caixas térmicas, bolos, frituras, picolés, frutas, comidas prontas e tudo o que se possa imaginar. Um cenário estranho que mais parecia uma feira livre entre muros. Eles também possuíam as chaves e cuidavam da circulação de pessoas no recinto prisional, que, muito embora com capacidade para 1,4 mil pessoas, contava na época com cinco mil presos se amontoando em insalubres condições. No sertão da Paraíba, uma região bastante assolada pela seca, a falta de água nas unidades prisionais era frequente. Em Cajazeiras, por exemplo, a solução para esse problema era recorrer a carros-pipas abastecidos no mesmo açude onde desaguava o esgoto da prisão.(BRASIL, 2012, p. 61-103).

Na Penitenciária Regional de Campina Grande no agreste paraibano, a circunstância insalubre se repetia, e, o forte odor denunciava o esgoto a céu aberto favorecendo a proliferação de insetos e doenças. No Maranhão, as unidades prisionais eram como campos de guerra, com ocorrências de crimes bárbaros e muitas rebeliões.No Piauí, a cada dez presos, sete ainda aguardavam julgamento e 
nesta unidade federativa havia apenas uma casa de custódia destinada exclusivamente aos presos provisórios. (BRASIL, 2012, p. 61-103).

Os juízes compararam algumas unidades do Rio Grande do Norte como verdadeiros calabouços, onde até pra respirar era difícil, dada a falta de ventilação e um mau cheiro insuportável. No Ceará, as unidades inspecionadas foram comparadas como ruínas, enquanto na Bahia o termo que melhor se aplicou foi campo de concentração, quando a comitivas e deparou com o pátio de determinada unidade em que o cenário desprovido de sensibilidade, era de total desrespeito aos direitos humanos. (BRASIL, 2012, p. 61-103).

No mesmo Estado, nas unidades prisionais femininas, mulheres aguardavam entre 6 a 18 meses para serem levadas à primeira audiência. Um verdadeiro desrespeito aos princípios da razoabilidade e do Devido Processo Legal. Em Alagoas, a verba pública era esbanjada com prisões ilegais. A prisão de uma pessoa que estava há um ano, seis meses e vinte e um dias encarcerada além do prazo previsto em lei, resultou em uma despesa de cerca de $\mathrm{R} \$ 30$ mil para Estado. Prejuízos semelhantes a este, são causados constantemente pelo elevado número de presos ainda sem condenação que, neste ente federativo, representa cerca de $60 \%$ da população carcerária (BRASIL, 2012, p. 61-103).

\subsection{Região Centro-Oeste}

Nesta região, a afronta aos direitos humanos era evidente ea precariedade das instalações prisionais saltava aos olhos. A região que abriga a capital do País e faz fronteira com a Bolívia e o Paraguai também era atingida pela superlotação, ocasião em que traficantes estrangeiros presos, contribuíam ainda mais para superlotar nossas prisões. Em Mato Grosso a população carcerária equivalia ao dobro da capacidade do sistema e metade dela era obrigada a dormir no chão por falta de assistência material. Em Goiás a omissão do Estado era tão grande que os presos mais antigos definiam para qual cela deveriam ir os novos presos. Os juízes encontraram uma cela com capacidade para duas pessoas em que havia trinta e cinco presos, uns sobre os outros com alguns até pendurados no teto. A direção da unidade ao ser interrogada sobre tal fato, respondeu que isto se dava de modo 
proposital por determinação dos presos que dominavam a unidade. (BRASIL, 2012, p. 111-127).

Em Mato Grosso do Sul, dezesseis homens dividiam uma cela com capacidade para apenas quatro. Quase quatro mil presos neste Estado foram beneficiados com liberdade provisória e progressão de regime (BRASIL, 2012, p. 111-127).

\subsection{Região Sudeste}

O Sudeste comportava e comporta até hoje mais da metade dos presos que cumprem pena no país. Não obstante ser a região mais rica, contudo amargava as mesmas aflições dos lugares menos aquinhoados financeiramente do país. Em Minas Gerais, algumas detentas eram obrigadas a tomar banho frio durante um inverno intenso e dividiam espaço com ratos e baratas.

No Rio de Janeiro, celas insalubres e com pouca ventilação também foram encontradas e em algumas unidades prisionais, se existiam materiais de limpeza, de higiene pessoal e remédios eram donativos de organizações não governamentais (ONGs) e de familiares dos presos. Na carceragem do Grajaú, Zona Norte da capital fluminense, enquanto alguns presos assumiam os serviços administrativos, na unidade prisional da Pavuna, os detentos eram responsáveis pela segurança interna do estabelecimento. No Estado do Espírito Santo, a situação encontrada foi tão drástica que chocou todo o país. Na ocasião, o Brasil foi denunciado à Comissão Interamericana de Direitos Humanos da Organização dos Estados Americanos (OEA), porque os presos eram tratados como animais, encarcerados dentro de celas metálicas (contêineres), sem ventilação, em condições precárias de higiene e sob o calor excessivo da região. (BRASIL, 2012, p. 135).

Em São Paulo, onde aconteceu o maior Mutirão Carcerário, irregularidades de todas as formas foram encontradas nas unidades inspecionadas. Na Penitenciária Feminina de Santana na capital, as detentas improvisavam miolo de pão como absorvente íntimo por falta de assistência material. Nas penitenciárias de Pirajuí, Martinópolis e Tupi Paulista, os juízes compararam as unidades como masmorras devido à densa escuridão na qual nada se podia enxergar. No Centro de Detenção 
Provisória I de Guarulhos foram encontrados 68 presos doentes, o consultório médico encontrava-se interditado por causa de infiltrações, o consultório dentário completamente alagado e os profissionais de saúde ausentes do local. Em uma das unidades prisionais de Pinheiros I, não havia janelas, pois as mesmas foram substituídas por concretos, impedindo a circulação de ar no interior das celas. Foi neste cenário desolador que a comitivas e deparou com 400 presos que já haviam cumprido suas penas e que ainda estavam encarcerados por falta de assistência jurídica (BRASIL 2012, p. 135-165).

\subsection{Região Sul}

O Sul do país, região formada por uma sociedade próspera e livre dos vários problemas que atingem as demais regiões, quando inspecionada, a surpresa foi tamanha. A comitiva encontrou presídios bem organizados, de padrão internacional, com verdadeiros sistemas de segurança, espaço suficiente para os detentos e com oportunidades para aqueles que querem abandonar a vida do crime. Essas unidades modelo, que mais lembravam presídios norte-americanos, estavam ocupadas com cerca de 14 mil pessoas cumprindo pena à essa época.Tal realidade permeada de justiça e dignidade foi encontrada no Paraná, mas, como nem tudo é perfeito, dentro do mesmo Estado, a poucos metros de distância, os juízes se depararam com uma situação completamente diferente. Aquele sistema carcerário oprimido, tal qual encontrados nos confins do país também estava presente na nobre região. Unidades prisionais assustadoras, em terríveis condições, abarrotadas de pessoas sofridas e abandonadas pelo Estado. Em Curitiba esse contraste foi notório, pois, no $12^{\circ}$ Distrito Policial, havia trinta presos em uma cela com capacidade para quatro detentos. Nesta unidade, os presos contavam com apenas um vaso sanitário, a comida sempre chegava azeda e na hora do café, utilizavam as próprias meias para prepará-lo (BRASIL, 2012, p. 169-181).

Em Santa Catarina, o resultado da análise feita pelo CNJ nos processos judiciais, revelou que a cada dez presos, um já deveria estar livre, pois, o cálculo das penas que é dever do judiciário, estava sendo desenvolvido pelo executivo e devido à falta de atuação da Defensoria Pública no Estado, o atendimento jurídico aos mais 
carentes restava prejudicado, pois, pessoas que já haviam cumprido pena, permaneciam presas ilegalmente por mais de três anos gerando ainda mais despesas para o Estado. No Rio Grande do Sul as unidades eram transformadas em verdadeiros centros de convenções de facções criminosas. Na época, pelo menos, quatro delas possuía legítima autoridade em quase todos os presídios da região metropolitana de Porto Alegre. Tal legitimidade foi fomentada pelo próprio Estado em prol de um falso estado de bonança e de tranquilidade dentro do próprio sistema com vistas a evitar mortes e sérios escândalos de cunho nacional e internacional. Tal consentimento convolou-se em verdadeiro descontentamento, pois o Estado perdeu totalmente o controle da situação e com isso criou-se um Estado Paralelo difícil de enfrentar. Um novo detento, por exemplo, ao ingressar em um dos presídios dominados por tais facções, era obrigado a filiar-se a uma delas. Neste caso, segundo os presos, tal filiação tornava-se até vantajosa, pois a assistência, como: complementos alimentares ajuda para a família e segurança não supridas pelo Estado, era mantida pelas facções (BRASIL, 2012, p. 169-181).

\section{DISCUSSÕES}

Enquanto nossas cadeias são entulhadas de pessoas que foram condenadas ou ainda aguardam julgamento, na maioria das vezes por envolvimento com drogas, roubo, furto e pequenos delitos que em sua maioria são caracterizados como crimes não violentos, os verdadeiros criminosos ficam impunes, pois agem covardemente usando as pessoas mais humildes da sociedade como aquelas de pouca ou nenhuma instrução, negras, de baixa renda ou oriunda de famílias pobres para colocarem em prática os seus planos ardilosos (MONTEIRO; CARDOSO, 2013, p. 104).

O Deputado Federal Domingos Dutra, relator da Comissão Parlamentar de inquérito (CPI), instaurada para investigar o sistema carcerário em 2008, ao se deparar com aqueles que compõem esta população,no decorrer das visitas aos estabelecimentos penais,inconformado com a deplorável situação, disse as seguintes palavras: "É mais fácil um camelo passar pelo fundo de uma agulha do que um rico permanecer na cadeia”, ao ver que a pena de prisão, em muitas vezes, 
não consegue atingir aos mais favorecidos, aos mais influentes, aos membros da classe média e alta (BRASIL, 2009, p. 46). Esta massa, composta de pessoas relativamente jovens, espoliada de instrução e excluída do meio social ainda antes de entrar no sistema prisional, continuará rejeitada após passar pelo mesmo, devido à falta de credibilidade da chamada ressocialização que o Estado oferece de forma precária e desprovida das condições mínimas para tal. O Estado, na qualidade de agente garantidor que através do sistema prisional deveria recuperar aqueles que cometeram crime para que novamente pudessem voltar ao convívio social, opera exatamente de modo contrário. Não fosse a benevolência das associações de reintegração social trabalhando com afinco pelo o restabelecimento civil dessas pessoas, organizações não governamentais lutando pela execução das políticas públicas neste sentido, grupos religiosos que empregam esforços para restabelecer esta massa, empresas que criam cotas em seus quadros funcionais para fomentar o ingresso de ex-presidiários no mercado de trabalho, talvez a situação estivesse ainda pior do que a que foi encontrada pelo Mutirão Carcerário.

É mera utopia pensar que o endurecimento das penas irá diminuir a criminalidade ou que a redução da maioridade penal irá dar jeito na situação, ou que a privatização das prisões será uma resposta ao caos penitenciário, ou ainda, que a implantação da pena de prisão perpétua e da pena de morte no nosso ordenamento jurídico será a solução para o problema. Ao que parece,o Estado ainda não encontrou saídas para essas adversidades que tanto afligi a sociedade brasileira.

\section{METODOLOGIA}

A metodologia utilizada no presente trabalho contemplou a pesquisa bibliográfica, de abordagem descritiva a partir de fontes disponíveis em bibliotecas e na internet, tais como: livros, artigos, doutrina e legislação, utilizando como base principal o relatório final do Mutirão Carcerário realizado pelo Conselho Nacional de Justiça (CNJ) no biênio 2010/2011. 


\section{DOS RESULTADOS}

O trabalho iniciou com pesquisas sobre a população carcerária e o seu avanço em números a partir de notícias veiculadas nos meios de comunicações. Os autores chegaram à conclusão que deveriam desenvolver o trabalho fazendo uma análise do relatório final do Mutirão Carcerário realizado pelo $\mathrm{CNJ}$ no biênio 2010/2011, por se tratar de publicação com riquíssimo conteúdo sobre o sistema prisional brasileiro.Com base neste documento final, chega-se ao seguinte resultado: as pessoas que passam pelo sistema prisional do país, além de cumprirem suas penas, são obrigadas a conviverem com algo a mais - o tratamento desumano aplicado pelo Estado, em muitas vezes pela sua conduta omissiva. No julgamento do HC 123.108/MG, o ministro Roberto Barroso registrou em seu voto que,

Mandar uma pessoa para o sistema é submetê-la a uma pena mais grave do que a que the foi efetivamente imposta, em razão da violência física, sexual e do alto grau de insalubridade das carceragens, notadamente devido ao grave problema da superlotação. (BRASIL, 2014c).

Neste sentido, há de se observar que, diversos preceitos da Constituição Federal são afrontados, como por exemplo, o princípio da dignidade da pessoa humana, considerado como o firme sustentáculo do Estado Democrático. Tal fato constitui-se também um verdadeiro insulto à Declaração Universal dos Direitos Humanos, que em seu artigo $5^{\circ}$ testifica: "Ninguém será submetido à tortura, nem a tratamento ou castigo cruel, desumano ou degradante". Novais (2017), afirma que, embora tais pessoas estejam justamente privadas de liberdade, incursas em processos penais por práticas de crimes, em um Estado Democrático, de maneira alguma podem perder sua dignidade na qualidade de pessoas humanas e, neste caso, o Estado deve manter o compromisso de garantir proteção e promoção de condições mínimas de vida digna para elas, algo que na maioria das vezes, mesmo dispondo de tais mecanismos, omite intervenções para coibir os tratamentos degradantes, contribuindo passivamente com o desrespeito aos Direitos Humanos (NOVAIS, 2017, p. 98-99, 136). Restam aqui demonstradas cristalinas violações de direitos dentro dos espaços especificamente apropriados para o cumprimento da lei. 
Diante de casos como estes, em que preceitos legais são transgredidos, Tolfo (2013), assim certifica:

Essa realidade de violações de direitos revela o problema da falta de efetividade de direitos que permeia a realidade brasileira. Mesmo tendo sido declarados no documento máximo da ordem jurídica (Constituição), verifica-se uma grande dificuldade no cumprimento dos direitos no plano material. Não se estabelece uma relação de compatibilidade entre o que está garantido constitucionalmente e o que se verifica concretamente na realidade brasileira (TOLFO, 2013, p. 37).

Cabe então ao Estado brasileiro através de suas instituições, principalmente às que dizem respeito ao sistema prisional e as demais que com ele mantém ligações, quer seja nas esferas jurídicas, políticas ou administrativas, dar efetividade aos direitos inerentes às pessoas em prisões, sobretudo aqueles garantidos na Constituição Federal, na Lei de Execução Penal e em todos os demais tratados internacionais em que o país é subscritor, com a finalidade de se erguer um sólido Estado Democrático composto de uma sociedade justa e solidária, assentada sobre o firme alicerce da dignidade da pessoa humana.

\section{CONSIDERAÇÕES FINAIS}

O artigo ora apresentado não teve por escopo esgotar o assunto referente à população carcerária visto que o mesmo é bastante abrangente e de questões divergentes que ocasionando de vez em quando calorosas discussões desde as mais tradicionais de senso comum aos grandes debates promovidos nos altos escalões jurídicos, políticos e acadêmicos. Ao apresentar o trabalho intitulado "População carcerária: uma análise do relatório final do Mutirão Carcerário realizado pelo Conselho Nacional de Justiça no biênio 2010/2011," propuseram os autores um estudo sobre alguns pontos considerados relevantes visando uma série de reflexões críticas sobre o sistema penitenciário brasileiro e expondo a realidade vivida por esta população mediante o "raio-x" do sistema prisional apresentado pelo Conselho Nacional de Justiça através do Mutirão Carcerário. 


\section{REFERÊNCIAS}

AO MENOS 33 presos são mortos em RR; ministro nega retaliação. Veja.com Online, Rio de Janeiro, 6 jan. 2017. Disponível em:

$<$ http://veja.abril.com.br/brasil/mais-de-30-presos-sao-encontrados-mortos-empresidio-em-rr/>. Acesso em: 07 Ago. 2018.

AUDIÊNCIA de Custódia: que decisões o juiz pode tomar? Conselho Nacional de Justiça, Rio de Janeiro, 27 jun 2015. Disponível em:

<http://www.cnj.jus.br/noticias/cnj/79963-audiencia-de-custodia-que-decisoes-o-juizpode-tomar>. Acesso em: 08 set. 2018.

BRASIL. Câmara dos Deputados. CPI Sistema Carcerário. Brasília: Biblioteca Digital da Câmara dos Deputados. 2009. Disponível em:

<http://bd.camara.leg.br/bd/handle/bdcamara/2701>. Acesso em: 10 ago. 2018.

BRASIL. Constituição (1988). Constituição da República Federativa do Brasil de 1988. Brasília, DF: Senado Federal, 1988. Disponível em:

<http://www.planalto.gov.br/ccivil_03/Constituicao/Constituicao.htm>. Acesso em: 30 dez. 2016.

BRASIL. Conselho Nacional de Justiça. Mutirão Carcerário: Raio-x do sistema penitenciário brasileiro. Brasília: CNJ, 2012. Disponível em:

<http://www.cnj.jus.br/publicacoes/livros>. Acesso em: 30 dez. 2016.

BRASIL.Conselho Nacional de Justiça. Novo diagnóstico de pessoas presas no Brasil. Brasília: CNJ, 2014a. Disponível em:

<http://www.cnj.jus.br/noticias/cnj/61762-cnj-divulga-dados-sobre-nova-populacaocarceraria-brasileira>. Acesso em: 30 dez. 2016.

BRASIL. Ministério da Justiça. Departamento Penitenciário Nacional. Levantamento Nacional de Informação Penitenciária (Infopen). Brasília, 2014b. Disponível em: $<$ https://www.justica.gov.br/noticias/mj-divulgara-novo-relatorio-do-infopen-nestaterca-feira/relatorio-depen-versao-web.pdf>. Acesso em: 20 dez. 2016.

BRASIL. Ministério da Justiça. Há 726.712 pessoas presas no Brasil. [20--?]. Disponível em: <http://www.justica.gov.br/news/ha-726-712-pessoas-presas-nobrasil>. Acesso em: 01 set. 2018.

BRASIL. Ministério da Justiça. Departamento Penitenciário Nacional. Sistema Penitenciário no Brasil: Dados consolidados. Brasília, 2008.

BRASIL. Supremo Tribunal Federal. Habeas Corpus $n^{0} 123.108$. Minas Gerais. $1^{a}$ Turma. Relator: Ministro Roberto Barroso. Impetrante: Defensoria pública da União. Órgão Coator: Superior Tribunal de Justiça - STJ. Paciente: José Robson Alves.

Data do Julgamento: 03/08/2014. 2014c. Disponível em: 
<http://www.stf.jus.br/portal/inteiroTeor/pesquisarlnteiroTeor.asp\#resultado>. Acesso em: 25 ago. 2018.

CORTE INTERAMERICANA DE DIREITOS HUMANOS. Resolução 11/2013: medica cautelar no. 367-13. 2013. Disponível em:

<http://www.oas.org/es/cidh/decisiones/pdf/MC367-13-pt.pdf>. Acesso em: 07 ago. 2018.

DECLARAÇÃO Universal dos Direitos Humanos. Disponível em: <https://www.unicef.org/brazil/pt/resources_10133.htm>. Acesso em: 17 ago. 2018.

EM 2001, megarrebelião promovida pelo PCC envolveu 29 penitenciárias. Folha de São Paulo Online, Rio de Janeiro, 14 mai. 2006. Disponível em: <http://www1.folha.uol.com.br/folha/c0otidiano/ult95u121461.shtml>. Acesso em: 07 ago. 2018.

LEMGRUBER, Julita; FERNANDES, Marcia. Impactos da assistência Jurídica a Presos Provisórios: um experimento na Cidade do Rio de Janeiro. Rio de Janeiro: ARP, 2011.

MONTEIRO, Felipe Mattos; CARDOSO, Gabriela Ribeiro. A seletividade do sistema prisional brasileiro e o perfil da população carcerária: Um debate oportuno. Revista Civitas, Porto alegre, v. 13, n. 1, jan/abr 2013.

NOVAIS, Jorge Reis. A dignidade da pessoa humana: dignidade e inconstitucionalidade.Coimbra:Almedina, 2017.

PAís pode economizar R $\$$ 4,3 bi com Audiência de Custódia, diz Lewandowski. Conselho Nacional de Justiça. Disponível em: <http://www.cnj.jus.br/noticias/cnj/79916-pais-pode-economizar-r-4-3-bi-comaudiencia-de-custodia-diz-lewandowski>. Acesso em: 09 set. 2018.

REBELIÃO deixa pelo menos 56 mortos em presídios do Amazonas. Veja.com Online, Rio de Janeiro, 2 jan. 2017. Disponível em: $<$ http://veja.abril.com.br/brasil/rebeliao-deixa-dezenas-de-mortos-em-presidios-doamazonas/>. Acesso em: 07 Ago. 2018.

SALLA, Fernando. Artigo: As rebeliões nas prisões: novos significados a partir da experiência brasileira. Revista Sociologias, Porto Alegre, ano 8, n. 16, p. 274-307, jul/dez 2006.

SAIBA como foi o massacre do Carandiru. Folha de São Paulo Online, Rio de Janeiro, 11 set. 2006. Disponível em:

<http://www1.folha.uol.com.br/folha/cotidiano/ult95u125842.shtml>. Acesso em: 07 ago. 2018. 
TOLFO, Andreia Candore. Direitos Humanos e a construção da cidadania. Revista Vivências, Erechim, v. 9, n. 17, p. 33-43, out. 2013. 